\title{
Long term results of double plate appliance and facemask combination in the treatment of Class III malocclusion: cephalometric analysis
}

\author{
Emine Kaygisiz, ${ }^{*}$ Erdal Bozkaya, Tuba Tortop, \\ Derviș Emre Ercan, Sema Yüksel \\ Department of Orthodontics, Faculty of Dentistry, Gazi \\ University, Ankara, Turkey
}

\begin{abstract}
OвJECtive: The aim of this study was to evaluate the long term results of double plate appliance and facemask combination (DPA-FM) in treating Class III malocclusions when growth potential of the patients was close to cease or ceased.
\end{abstract}

Materials AND Method: The material consisted of the pretreatment (T1), posttreatment (T2), and long term (T3) lateral cephalometric and the hand-wrist radiographs of 13 patients ( 5 females, 8 males; mean chronological age: $11.1 \pm 1.40$ years) with skeletal and dental Class II malocclusion treated with DPA-FM combination. The mean DPA-FM treatment time was $10.8 \pm 1.88$ months. The hand-wrist growth and developmental stages were MP3u or $\mathrm{Ru}$ at T3. The mean follow-up period was $5.0 \pm 1.98$ years. Friedman's Two-Way ANOVA and Wilcoxon signed-rank tests were used to evaluate the treatment (T2-T1), followup (T3-T2) and overall (T3-T1) results.

RESULTS: With the DPA-FM therapy, SNA and ANB angles increased $(p<0.001)$; however, no significant differences were found in these parameters during T3-T2 period $[p=0.655$ (SNA), $p=0.805$ (ANB)]. Significant increases were found in $\mathrm{N} \perp$ FH-A distance during the treatment $(p<0.01)$ and follow-up $(p<0.05)$ periods. Molar relation showed significant increases with DPA-FM in both the treatment and overall period $(p<0.001)$. Overjet increased significantly during the treatment $(p<0.001)$, followup $(p<0.05)$, and overall $(p<0.001)$ periods. Significant protrusion of upper incisors (U1/NA) was observed during the treatment, follow-up, and overall periods $(p<0.05)$. U6/ PP and L6/MP angles did not change during the DPAFM treatment; however, these parameters decreased

Received: October 18, 2017; Accepted: March 7, 2018

${ }^{*}$ Corresponding author: Dr. Emine Kaygisiz, Gazi University, Faculty of

Dentistry, Department of Orthodontics, Bișkek Cad. (8. Cad.), 82. Sk., No: 4

06510, Emek, Ankara, Turkey;

E-mail: dt.emineulug@mynet.com significantly during the follow-up and overall periods $(\mathrm{p}<0.05)$

ConCLusion: In the treatment of Class III malocclusion, the DPA-FM appliance was effective. The skeletal and dental sagittal changes achieved by orthopedic treatment were maintained in the long term.

KEYwORDS: Angle Class III; follow-up studies; malocclusion; orthodontic appliances; orthodontics

Citation: Kaygisiz E, Bozkaya E, Tortop T, Ercan DE, Yükse $S$. Long term results of double plate appliance and facemask combination in the treatment of Class III malocclusion: cephalometric analysis. Acta Odontol Turc 2018;35(3):62-8

EdıTOR: Güven Kayaoğlu, Gazi University, Ankara, Turkey

Copyright: (C) 2018 Kaygisiz et al. This work is licensed under a Creative Commons Attribution License. Unrestricted use, distribution and reproduction in any medium is permitted provided the original author and source are credited.

FundING: None declared.

Conflict OF INTEREST: The authors declare no conflict of interest related to this study.

\section{INTRODUCTION}

Skeletal Class III malocclusions remain one of the most challenging problems due to the relapse of skeletal problem. The effects of maxillary protraction by facemask (FM) therapy on skeletal and dentoalveolar components of craniofacial region are well established in the treatment of skeletal Class III malocclusions characterized by maxillary hypoplasia. ${ }^{1-6}$ Besides, successful outcomes of Class III malocclusion have been reported with the use of functional appliances, including Frankel III, double plate appliances (DPA), and reverse twin-block. ${ }^{2,7-11}$

The DPA was designed as an intraoral opposed angulated acrylic blocks. Sagittal skeletal changes during DPA treatment was less than FM therapy. ${ }^{9}$ However, greater dental contribution to Class III treatment and more satisfying vertical dental and skeletal changes were shown in the DPA group. ${ }^{9}$ In order to obtain more favorable dental effects with FM 
therapy, combined use of FM and DPA was offered. ${ }^{2}$ Gencer et al. ${ }^{2}$ reported significant changes in maxillary growth and position with DPA-FM combination and less effect on mandible than FM therapy.

In several follow-up studies of facemask, evaluations were done on growing subjects. ${ }^{12-15}$ Shortterm improvements does not always assure longterm success. ${ }^{5,16}$ There is still a risk for relapse due to substantial growth potential. A longer follow-up period is needed to understand the real growth alterations after Class III treatment.

The success of the orthopedic treatment, age at the beginning of the treatment, excessive mandibular growth, overcorrection, overbite, and overjet at the end of the treatment were the important factors in determining long term outcomes in Class III malocclusions. 4,6,13,17

In literature, long-term evaluations of FM were well documented; $3-6,13,14,16$ however, there is no study evaluating the stability of DPA-FM combination therapy. Therefore, the aim of this study was to evaluate the long term results of DPA-FM combination in treating Class III malocclusions when growth potential of the patients was close to cease or ceased.

\section{Materials and Method}

\section{Patient selection}

This study was approved by the Ethical Committee of Gazi University (\#77082166-604.01.02).This retrospective study was carried out on the pretreatment (T1), posttreatment (T2), and long-term (T3) lateral cephalometric and hand-wrist radiographs of 13 patients (5 females, 8 males; mean chronological age: $11.1 \pm 1.40$ years) with Angle Class III malocclusion characterized by an anterior cross-bite and/or Class III molar relationship with skeletal Class III malocclusion (ANB angle $\leq 0^{\circ}$ ) due to maxillary retrusion or a combination of maxillary retrusion and mandibular protrusion. None of the patients had a congenital anomaly in the craniofacial region. All patients were treated with DPADelaire type FM combination (Figure 1).

\section{Appliance design}

The DPA-FM combination was designed as in studies previously reported. ${ }^{2,18}$ Construction bites for DPA were taken without sagittal activation and with a 5-6 mm. vertical opening at the molar region. The appliances had modified Adams clasps at the molar region and $\mathrm{F}$ clasps between upper lateral incisors and canines. Inclination between the acrylic blocks was $30^{\circ} .^{2}$ The protraction elastics were attached to the $\mathrm{F}$ clasps and a force of $350-400 \mathrm{~g}$ per side was applied and the patients were instructed to wear it approximately 16 hours a day. At the beginning of treatment and every 3 weeks during treatment, $2 \mathrm{~mm}$ was trimmed from the posterior region of the lower angulated acrylic block and the anterior region of the upper angulated acrylic block. The aim of this trimming was to facilitate the free sliding of the upper and lower pieces of the appliance along the angulated surfaces. The mean treatment time was $10.8 \pm 1.88$ months.

\section{Radiographic evaluation}

Lateral cephalograms and hand-wrist radiographs were taken at the beginning of DPA-FM (T1), after achieving at least a positive overjet and/or Class I molar occlusion (T2) and long-term period (T3). The mean follow-up period was $5.0 \pm 1.98$ years. The hand-wrist growth and developmental stages were MP3u or Ru at T3. Fixed therapy was performed in all patients between T2 and
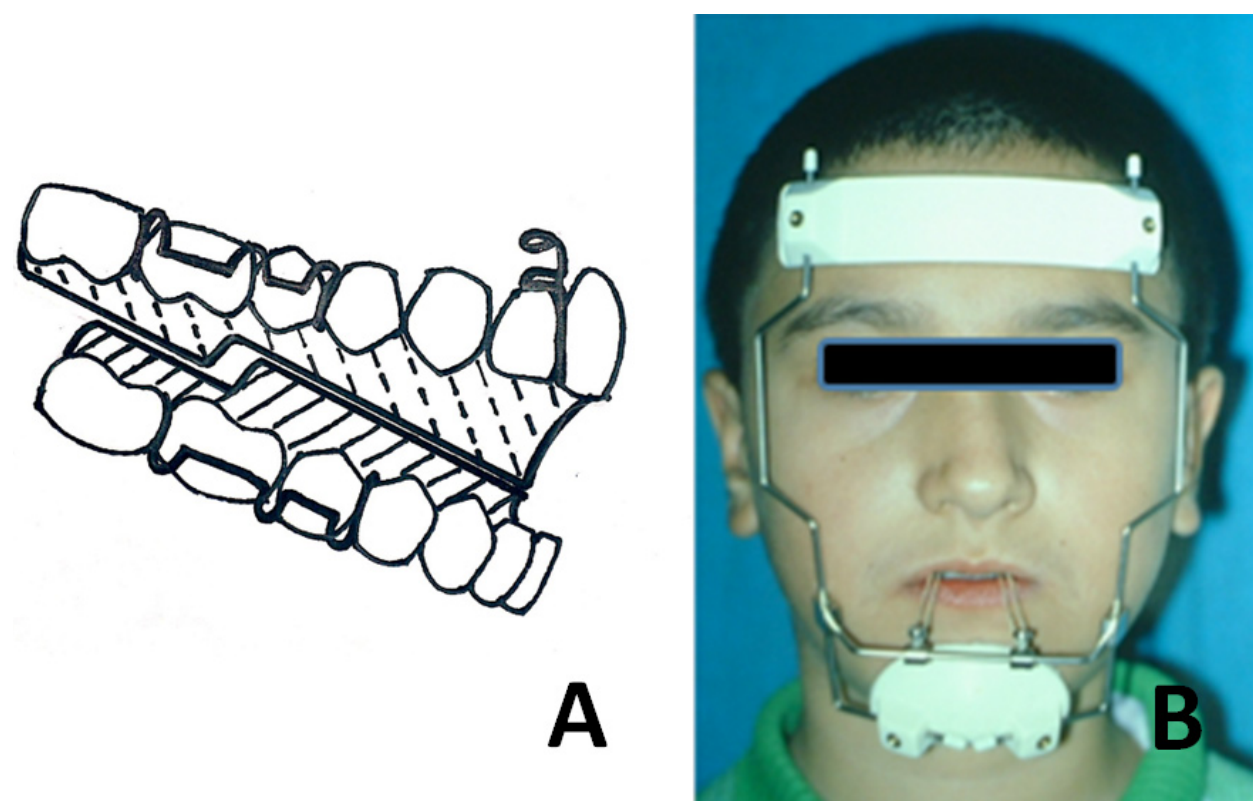

Figure 1. Extraoral and intraoral views of the DPA-FM combination used in this study; (A) representative intraoral appliance, (B) extraoral view 


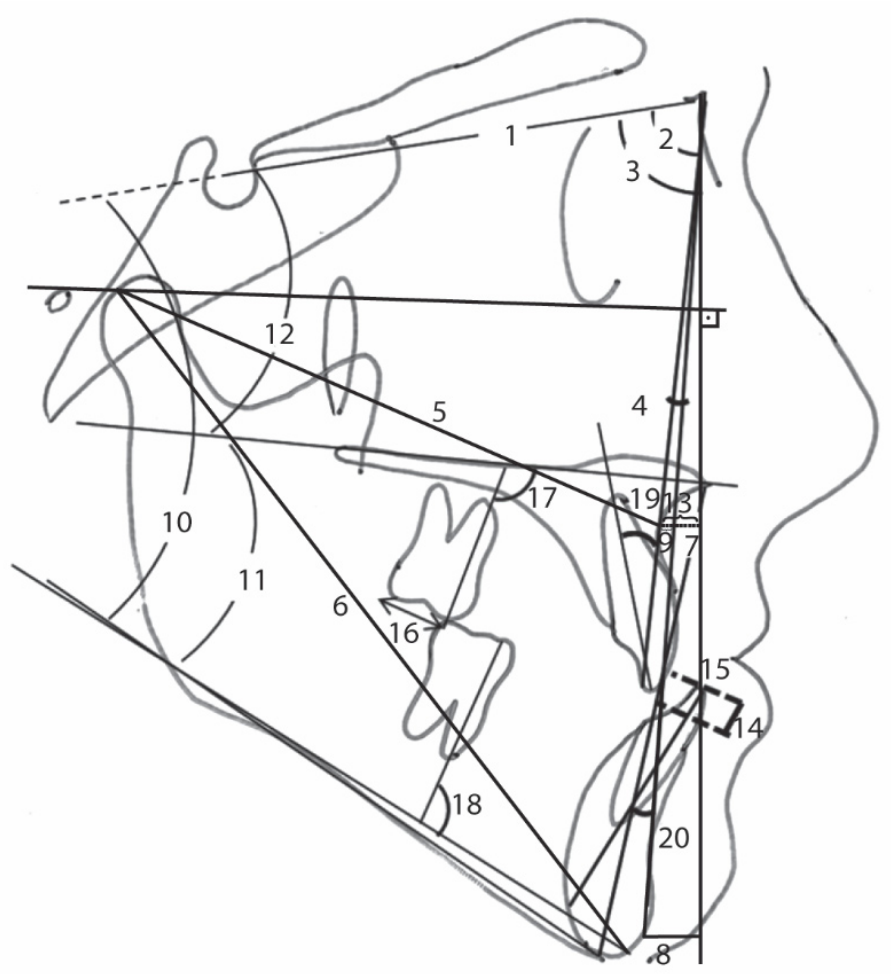

Figure 2. Cephalometric measurements used in the study; 1: SN, 2: SNA, 3: SNB, 4: ANB, 5: CoA,

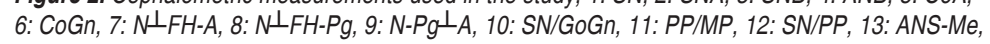
14: Overbite, 15: Overjet, 16: molar relation, 17: U6/PP, 18: L6/MP, 19: U1/NA, 20: L1/NB

T3 periods. Remaining growth potential was assessed with hand-wrist radiographs according to Grave \& Brown ${ }^{19}$ at T3 to determine whether the growth potential was close to cease or ceased.

Ten linear and 10 angular measurements were evaluated (Figure 2). The lateral cephalometric radiographs of 8 subjects were retraced, and measurements were repeated after 15 days. Method error coefficients were calculated and found to be within acceptable limits (range 0.98-1.00).

\section{Statistical analysis}

Statistical analysis was performed with IBM SPSS Statistics Version 20.0 (SPSS Inc., Armonk, NY, USA). The normality of the data was tested with Shapiro Wilk's test. Because the data were not normally distributed, Friedman's Two-Way ANOVA and Wilcoxon signedrank tests were used. The level of significance used was $p<0.05$.

\section{RESULTS}

Descriptive data, treatment changes and long term results of DPA-FM combination therapy were given in Table 1.

SN showed significant increase during treatment (T2-T1; $p<0.05$ ), follow-up (T3-T2; $p<0.01$ ), and overall period (T3-T1; $p<0.001)$. During DPA-FM therapy, SNA angle $(p<0.001)$ and $N \perp F H-A$ distance $(p<0.01)$ increased. A significant decrease in $\mathrm{N} \perp \mathrm{FH}-\mathrm{A}$ distance $(p<0.05)$ during T3-T2 period was observed. Overall changes (T3-T1) showed a significant increase in SNA angle $(\mathrm{p}<0.05)$.

ANB angle increased during T2-T1 $(p<0.001)$ and T3-T1 periods $(p<0.01)$; however, no significant difference was found during T3-T2 period in this parameter $(p=0.805)$.

There were significant increases in Co-A length during all periods $(p<0.001)$. Also, Co-Gn showed significant increase during treatment $(p<0.05)$, followup $(p<0.001)$, and overall $(p<0.001)$ periods. $\mathrm{N}-\mathrm{Pg} \perp \mathrm{A}$ increased significantly during therapy $(p<0.05)$ and overall period $(p<0.01)$.

$\mathrm{PP} / \mathrm{MP}$ angle showed a significant increase during DPA-FM therapy $(p<0.01)$ and a significant decrease during follow-up period $(p<0.01)$. By the evaluation of the overall changes (T3-T1), a significant decrease was observed in this angle $(p<0.05)$. A significant decrease during DPA-FM therapy $(p<0.01)$ and a significant increase $(p<0.05)$ during follow-up were determined in SN/PP angle. There were significant increases in ANSMe during therapy $(p<0.01)$, follow-up $(p<0.01)$ and overall periods $(p<0.001)$.

Overbite decreased significantly with DPA-FM therapy $(p<0.05)$. Overjet and molar relation showed significant increases with DPA-FM treatment $(p<0.001)$, but a significant decrease in overjet $(p<0.05)$ was 
Table 1. Descriptive statistics, treatment effects and long term changes after DPA-FM therapy

\begin{tabular}{|c|c|c|c|c|c|c|c|c|c|c|c|c|c|c|}
\hline \multirow{2}{*}{$\begin{array}{l}\text { Cephalometric } \\
\text { measurements }\end{array}$} & \multicolumn{3}{|c|}{ T1 } & \multicolumn{3}{|c|}{ T2 } & \multicolumn{3}{|c|}{ T3 } & \multicolumn{2}{|c|}{ Friedman } & \multicolumn{3}{|c|}{$P$ value } \\
\hline & $\begin{array}{c}\text { Median } \\
\text { [min-max] }\end{array}$ & Mean & Sd & $\begin{array}{c}\text { Median } \\
\text { [min-max] }\end{array}$ & Mean & Sd & $\begin{array}{c}\text { Median } \\
\text { [min-max] }\end{array}$ & Mean & Sd & $x^{2}$ & p & T2-T1 & T3-T2 & T3-T1 \\
\hline $\mathrm{SN}[\mathrm{mm}]$ & $\begin{array}{c}67 \\
{[61-75]}\end{array}$ & 67.2 & 3.47 & $\begin{array}{c}69 \\
{[64-77]}\end{array}$ & 69.0 & 3.22 & $\begin{array}{c}74 \\
{[64-80]}\end{array}$ & 73.2 & 3.95 & 22.6 & 0.001 & 0.005 & 0.009 & 0.001 \\
\hline SNA [ $\left.{ }^{\circ}\right]$ & $\begin{array}{c}77 \\
{[72-83]}\end{array}$ & 77.0 & 3.35 & $\begin{array}{c}80 \\
{[75-86]}\end{array}$ & 79.5 & 3.13 & $\begin{array}{c}80 \\
{[75-87]}\end{array}$ & 79.9 & 3.84 & 14 & 0.001 & 0.001 & 0.655 & 0.005 \\
\hline SNB $\left[{ }^{\circ}\right]$ & $\begin{array}{c}80 \\
{[74-85]}\end{array}$ & 80.0 & 3.60 & $\begin{array}{c}80 \\
{[74-84]}\end{array}$ & 79.3 & 3.63 & $\begin{array}{c}80 \\
{[74-85]}\end{array}$ & 79.7 & 3.42 & 4.0 & 0.138 & 0.058 & 0.721 & 0.700 \\
\hline ANB $\left[{ }^{\circ}\right]$ & {$\left[(-7)^{-2}-(-1)\right]$} & -3.0 & 2.00 & {$\left[\begin{array}{c}1 \\
{[(-4)-3]}\end{array}\right.$} & 0.2 & 2.12 & $\stackrel{2}{2}[(-5)-3]$ & 0.3 & 2.63 & 18.5 & 0.001 & 0.001 & 0.805 & 0.002 \\
\hline $\mathrm{CoA}[\mathrm{mm}]$ & $\begin{array}{c}81 \\
{[75-95]}\end{array}$ & 81.9 & 5.48 & $\begin{array}{c}85 \\
{[77-101]}\end{array}$ & 85.5 & 6.14 & $\begin{array}{c}93 \\
{[83-107]}\end{array}$ & 92.9 & 6.70 & 26 & 0.001 & 0.001 & 0.001 & 0.001 \\
\hline CoGn [mm] & $\begin{array}{c}113 \\
{[105-127]}\end{array}$ & 113.8 & 7.19 & $\begin{array}{c}113 \\
{[105-132]}\end{array}$ & 115.3 & 8.06 & $\begin{array}{c}127 \\
{[116-142]}\end{array}$ & 127.5 & 8.76 & 23.2 & 0.001 & 0.014 & 0.001 & 0.001 \\
\hline $\mathrm{N}^{\perp}$ FH-A [mm] & {$[(-11)-(-1)]$} & -4.1 & 2.97 & {$[(-8)-5]$} & -1.5 & 3.19 & {$[[-9.5]-8]$} & -2.7 & 4.75 & 12.2 & 0.002 & 0.003 & 0.033 & 0.328 \\
\hline $\mathrm{N}^{\perp} \mathrm{FH}-\mathrm{Pg}[\mathrm{mm}]$ & {$[(--2)-2]$} & -1.7 & 2.71 & {$\left[\begin{array}{c}0 \\
{[(-7)-5]}\end{array}\right.$} & -0.5 & 3.59 & {$\left[\begin{array}{c}-3 \\
{[(-16)-6]}\end{array}\right.$} & -4.1 & 6.24 & 5.5 & 0.066 & 0.107 & 0.123 & 0.208 \\
\hline $\mathrm{N}-\mathrm{Pg} \perp^{\perp} \mathbf{A}[\mathrm{mm}]$ & {$\left[\begin{array}{c}-2.5 \\
{[(-8.5)-2]}\end{array}\right.$} & -3.1 & 3.46 & $\begin{array}{c}0 \\
{[(-8)-3]}\end{array}$ & -1.0 & 3.07 & $\begin{array}{c}0 \\
{[(-8)-4]}\end{array}$ & -0.7 & 3.28 & 9.5 & 0.008 & 0.030 & 0.918 & 0.006 \\
\hline SN/GoGn [ [ $]$ & $\begin{array}{c}33 \\
{[25-38]}\end{array}$ & 32.0 & 4.01 & $\begin{array}{c}34 \\
{[26-38]}\end{array}$ & 32.7 & 4.13 & $\begin{array}{c}30 \\
{[25-40]}\end{array}$ & 31.5 & 4.46 & 3.1 & 0.216 & 0.083 & 0.328 & 0.504 \\
\hline PP/MP [ [ $\left.{ }^{\circ}\right]$ & $\begin{array}{c}26 \\
{[19-37]}\end{array}$ & 27.0 & 4.99 & $\begin{array}{c}30 \\
{[21-37]}\end{array}$ & 28.5 & 4.74 & $\begin{array}{c}24 \\
{[17-38]}\end{array}$ & 25.2 & 5.56 & 9.6 & 0.008 & 0.009 & 0.007 & 0.020 \\
\hline SN/PP $\left[{ }^{\circ}\right]$ & $\begin{array}{c}8 \\
{[3-13]}\end{array}$ & 7.6 & 3.01 & $\begin{array}{c}6 \\
{[2-11]}\end{array}$ & 6.2 & 3.12 & $\begin{array}{c}7 \\
{[4-15]}\end{array}$ & 8.4 & 3.73 & 11.9 & 0.003 & 0.005 & 0.035 & 0.343 \\
\hline ANS-Me [mm] & $\begin{array}{c}64 \\
{[52-78]}\end{array}$ & 64.0 & 7.56 & $\begin{array}{c}67 \\
{[55-79]}\end{array}$ & 66.5 & 7.07 & $\begin{array}{c}72 \\
{[56-91]}\end{array}$ & 73.1 & 8.62 & 21.2 & 0.001 & 0.003 & 0.003 & 0.001 \\
\hline Overbite [mm] & $\left.\stackrel{2}{2}^{2}-6\right]$ & 2.5 & 1.98 & {$[(-1)-4]$} & 1.3 & 1.55 & {$\left[\begin{array}{l}2 \\
{[(-2)-3]}\end{array}\right.$} & 1.7 & 1.28 & 5.3 & 0.071 & 0.021 & 0.178 & 0.305 \\
\hline Overjet [mm] & {$\left[\begin{array}{c}-3 \\
{[(-5)-0]}\end{array}\right.$} & -2.5 & 1.65 & $\begin{array}{c}3 \\
{[0-7]}\end{array}$ & 2.9 & 1.69 & ${ }^{2}$ & 1.9 & 0.65 & 22.4 & 0.001 & 0.001 & 0.024 & 0.001 \\
\hline $\begin{array}{l}\text { Molar relation } \\
{[\mathrm{mm}]}\end{array}$ & {$[(-9)-(-2)]$} & -4.7 & 2.45 & {$\left[\begin{array}{c}0 \\
{[(-7)-5]}\end{array}\right.$} & 0.1 & 3.13 & $\begin{array}{c}2 \\
{[0-4]}\end{array}$ & 2.4 & 1.37 & 20.5 & 0.001 & 0.001 & 0.071 & 0.001 \\
\hline U6/PP $\left[{ }^{\circ}\right]$ & $\begin{array}{c}100 \\
{[93-106]}\end{array}$ & 100.4 & 4.28 & $\begin{array}{c}99 \\
{[86-104]}\end{array}$ & 98.5 & 5.24 & $\begin{array}{c}84 \\
{[77-95]}\end{array}$ & 85.1 & 4.89 & 14.9 & 0.001 & 0.248 & 0.002 & 0.002 \\
\hline L6/MP [ [ $\left.{ }^{\circ}\right]$ & $\begin{array}{c}94 \\
{[88-102]}\end{array}$ & 94.4 & 3.78 & $\begin{array}{c}94 \\
{[83-100]}\end{array}$ & 93.6 & 5.03 & $\begin{array}{c}78 \\
{[72-86]}\end{array}$ & 78.8 & 4.41 & 19.9 & 0.001 & 1.000 & 0.001 & 0.001 \\
\hline U1/NA [ $\left.{ }^{\circ}\right]$ & $\begin{array}{c}24 \\
{[16-31]}\end{array}$ & 23.8 & 4.68 & $\begin{array}{c}27 \\
{[21-34]}\end{array}$ & 26.8 & 4.42 & $\begin{array}{c}29 \\
{[22-48]}\end{array}$ & 30.9 & 7.20 & 8.0 & 0.019 & 0.011 & 0.041 & 0.011 \\
\hline L1/NB [ $\left.{ }^{\circ}\right]$ & $\begin{array}{c}22 \\
{[10-28]}\end{array}$ & 20.0 & 5.27 & $\begin{array}{c}21 \\
{[10-30]}\end{array}$ & 19.8 & 5.59 & $\begin{array}{c}20 \\
{[11-30]}\end{array}$ & 20.4 & 6.31 & 0.3 & 0.856 & 0.449 & 0.918 & 0.753 \\
\hline
\end{tabular}

T2-T1: treatment period; T3-T2: follow-up period; T3-T1: overall period; Sd: standard deviation

found during follow-up period (T3-T2). Evaluation of overall changes showed that overjet and molar relation increased significantly $(p<0.001)$. U6/PP and L6/MP angles did not change during DPA-FM treatment; however, these parameters decreased significantly during follow-up ( $p<0.01, p<0.001$; respectively). Overall changes also showed significant decreases in U6/ PP $(p<0.01)$ and L6/MP $(p<0.001)$ angles. Significant protrusion of upper incisors (U1/NA) was observed during all periods $(p<0.05)$.

\section{Discussion}

The real success of a therapy is the long-term stability of the results achieved by treatment. A tendency toward Class III relapse was reported when the mandible rotated downward and backward with FM therapy..$^{3-5}$ The main purpose of the DPA was to withstand the possible tendency toward posterior rotation of the mandible. ${ }^{9,18}$ Though similar vertical skeletal changes were reported in DPA-FM and FM treatments; sagittal skeletal and dental changes in the mandible showed significant differences between these treatment 
modalities. ${ }^{2}$ Long term stability of appliances used in the treatment of Class III malocclusion were evaluated in several researches; $3,4,6,13,16,17,20-22$ however, there is not any follow-up study regarding DPA-FM combination therapy. In this study, it was aimed to evaluate the longterm stability of DPA-FM combination therapy in Class III malocclusion.

The significant increase in SNA during DPA-FM therapy was maintained during follow-up period, and overall improvement in this angle was found significant. In concomitant with this, similar results have been reported with FM therapy. ${ }^{6,16,23-25}$

The results indicated that there were no significant changes in SNB angle and horizontal movement of pogonion ( $\mathrm{N} \square \mathrm{FH}-\mathrm{Pg}$ ) during DPA-FM therapy. That might be defined as the less effect of this appliance on the mandible. In contrast with this, backward rotation associated with a reduction in mandibular growth was reported with FM appliance which was attributed to the chincap effect. ${ }^{2,13,26}$ During follow-up in the present study, the position of mandible did not change which can be defined as a stability. In contrast with this, anterior rotation of the mandible was reported due to a return to previous growth pattern during FM.4,16,17,23 Wells et al. ${ }^{27}$ also observed that posterior rotation of the mandible with FM appliance increased the chance of long term failure of treatment.

The significant improvement in maxillomandibular relation during DPA-FM combination treatment was mainly caused by the maxilla in this study. This result was in agreement with the findings of several studies on treatment of Class III malocclusion..$^{25,28,29}$ No significant change was found in ANB angle during long-term period (T3-T2) and this can be interpreted as the stability of maxillomandibular relationship. Nevertheless, in follow-up studies regarding FM therapy non-significant increase in SNB angle and a significant decrease in ANB angle were reported. ${ }^{12,30}$ Mandall et al. ${ }^{21}$ reported that changes in SNA, SNB and ANB angles with FM therapy did not show long term differences compared to a control group, but pointed out that this kind of treatment reduced the need for orthognathic surgery.

Both CoA and CoGn lengths showed significant increases during follow-up period. Janson et al. ${ }^{20}$ emphasized that the significant increase in mandibular length during the posttreatment period was compensated by a significant increase in maxillary length. So, apical base relationship was found to be similar to the control group. $^{20}$

Increase in lower facial height (ANS-Me) was significant during all periods which might be due to the significant anterior rotation of the maxilla during treatment (SN/PP) and continued vertical growth in all periods. ${ }^{12}$ During follow-up period, maxillary rotation changed into a clockwise direction. As, SN/GoGn angle showed no significant changes in any of the periods, no rotational changes occurred in mandible. Changes in palato-mandibular angle in all periods seemed to be related to the rotational changes in palatal plane. Thus, it could be suggested that vertical stability after DPAFM therapy was successful. This finding is consistent with the long-term results of FM studies. ${ }^{16,20}$ However, Hägg et al..$^{5}$ reported significant posterior rotation and increases in vertical dimensions. Mandall et al. ${ }^{21}$ emphasized that the clockwise rotation of maxilla and mandible during protraction of maxilla provides a more favorable facial profile compared to control group which have an anti-clockwise growth direction.

In several facemask studies, proclination of the upper incisors and retroclination of the lower incisors by the effect of maxillary protraction were reported..$^{18,25,31}$ In this study, proclination of upper incisor was significant both during treatment and follow-up periods. However, no significant change was found in lower incisors, as the contact to the acrylic surface of DPA prevent retrusion effect of the facemask. Cozza et al. ${ }^{30}$ also reported no changes in mandibular incisors both during the treatment and long-term period of bite-block and FM study. On the contrary, significant retrusion of the mandibular incisors was reported with other removable appliances. ${ }^{7,8,32}$

Both overjet and molar relationship improved significantly due to the dental and skeletal changes achieved by DPA treatment. A significant relapse in overjet was occurred during follow-up period (T3-T2), but eventually the positive overjet was maintained (T3-T1). This finding was in accordance with previous literature with data ranging from $67 \%$ to $72 \%$ of patients having a positive overjet. 5,33 In a previous study, the decrease in overjet during posttreatment was found to be correlated with the increase in mandibular length. In this study, both maxillary and mandibular lengths showed significant increases, but increase in mandibular length was greater and might have played an important role in the decrease of overjet. ${ }^{20}$

U6/PP and L6/MP angles did not change during DPA-FM treatment; however, significant decreases were observed during T3-T2 period. Upper molar tipping seems to be prevented by the guidance of the angulated surfaces with DPA-FM. Mesial tipping of upper and lower molars during follow-up period was possibly due to both the transition from mixed to permanent dentition and the effect of fixed appliances.

In a meta-analysis study, ${ }^{29}$ it was concluded that there was insufficient evidence to assess the long term stability of early Class III treatment. The limitations of this study were lack of control group and small sample size. However, both because of ethical purposes and difficulties relating to the follow-up period, it is not easy to set up the long term studies. Nevertheless, being the first study that evaluated the long term stability of DPAFM therapy provides a unique contribution to literature.

\section{Conclusion}

In the treatment of Class III malocclusion, DPA-FM 
appliance was effective. The skeletal and dental sagittal changes achieved by orthopedic treatment were preserved during long-term period. Vertical stability was maintained both during DPA-FM combination treatment and follow-up periods.

\section{ACKNOWLEDGEMENTS}

This study was presented at the 14th International Turkish Journal of Orthodontics Congress in Ankara, Turkey; October 25-29, 2014.

\section{REFERENCES}

1. Tortop T, Keykubat A, Yuksel S. Facemask therapy with and without expansion. Am J Orthod Dentofacial Orthop 2007;132:467-74.

2. Gencer D, Kaygisiz E, Yüksel S, Tortop T. Comparison of doubleplate appliance/facemask combination and facemask therapy in treating Class III malocclusions. Angle Orthod 2015;85:278-83.

3. Williams MD, Sarver DM, Sadowsky PL, Bradley E. Combined rapid maxillary expansion and protraction facemask in the treatment of Class III malocclusions in growing children: a prospective long-term study. Semin Orthod 1997;3:265-74.

4. Ngan PW, Hagg U, Yiu C, Wei SH. Treatment response and long term dentofacial adaptations to maxillary expansion and protraction. Semin Orthod 1997;3:255-64.

5. Hägg U, Tse A, Bendeus M, Rabie ABM. Long-term follow-up of early treatment with reverse headgear. Eur J Orthod 2003;25:95-102.

6. Westwood PV, McNamara Jr JA, Baccetti T, Franchi L, Sarver DM. Long-term effects of Class III treatment with rapid maxillary expansion and facemask therapy followed by fixed appliances. Am J Orthod Dentofac Orthop 2003;123:306-20.

7. Tortop T, Kaygisiz E, Gencer D, Yuksel S, Atalay Z. Modified tandem traction bow appliance compared with facemask therapy in treating Class III malocclusions. Angle Orthod 2014;84:642-8.

8. Atalay Z, Tortop T. Dentofacial effects of a modified tandem traction bow appliance. Eur J Orthod 2010;32:655-61.

9. Gencer D, Hasanoğlu Nalcı N, Yuksel S, Tortop T. Effects of double plate - facemask appliance on dentofacial structures. GÜ Diş Hek Fak Derg 2009;26: 163-70.

10. Seehra J, Fleming PS, Dibiase AT. Reverse Twin Block appliance for early dental Class III correction. J Clin Orthod 2010;44:602-10.

11. Fränkel R. Maxillary retrusion in Class 3 and treatment with the function corrector 3. Rep Congr Eur Orthod Soc 1970:249-59.

12. Arman A, Toygar TU, Abuhijleh E. Evaluation of maxillary protraction and fixed appliance therapy in Class III patients. Eur J Orthod 2006;28:383-92.

13. Baccetti T, Franchi L, McNamara Jr JA. Treatment and posttreatment craniofacial changes after rapid maxillary expansion and facemask therapy. Am J Orthod Dentofacial Orthop 2000;118:404-13.

14. Ghiz MA, Ngan P, Gunel E. Cephalometric variables to predict future success of early orthopedic Class III treatment. Am J Orthod Dentofacial Orthop 2005;127:301-6.

15. Deguchi T, Kanomi R, Ashizawa Y, Rosenstein SW. Very early face mask therapy in Class III children. Angle Orthod 1999;69:349-55.

16. Gallagher R, Miranda F, Buschang P. Maxillary protraction: treatment and posttreatment effects. Am J Orthod Dentofacial Orthop 1998;113:612-9.

17. Chen L, Chen R, Yang Y, Ji G, Shen G. The effects of maxillary protraction and its long-term stability-a clinical trial in Chinese adolescents. Eur J Orthod 2012;34:88-95.

18. Üçem TT, Üçüncü N, Yüksel S. Comparison of double-plate appliance and facemask therapy in treating Class III malocclusions. Am J Orthod Dentofacial Orthop 2004;126:672-9.
19. Grave KC, Brown T. Skeletal ossification and the adolescent growth spurt. Am J Orthod 1976;69:611-9.

20. Janson G, Caldas W, Garib DG, Foncatti CF. Long-term stability of Class III malocclusion nonextraction treatment. J World Fed Orthod 2017;6:20-7

21. Mandall N, Cousley R, DiBiase A, Dyer F, Littlewood S, Mattick R et al. Early class III protraction facemask treatment reduces the need for orthognathic surgery: a multi-centre, two-arm parallel randomized, controlled trial. J Orthod 2016;43:164-75.

22. Kaygisiz E, Yuksel S. Evaluation of the long-term results of facemask. Acta Odontol Turc 2014;31:127-33.

23. Macdonald KE, Kapust AJ, Turley PK. Cephalometric changes after the correction of Class III malocclusion with maxillary expansion/ facemask therapy. Am J Orthod Dentofacial Orthop 1999;116:13-24.

24. Shanker S, Ngan P, Wade D, Wade D, Beck M, Yiu C, et al. Cephalometric A point changes during and after maxillary protraction and expansion. Am J Orthod Dentofacial Orthop 1996;110:423-30.

25. Chong YH, Ive JC, Årtun J. Changes following the use of protraction headgear for early correction of Class III malocclusion. Angle Orthod 1996;66:351-62.

26. Merwin D, Ngan P, Hagg U, Yiu C, Wei SH. Timing for effective application of anteriorly directed orthopedic force to the maxilla. Am J Orthod Dentofacial Orthop 1997;112:292-9.

27. Wells AP, Sarver DM, Proffit WR. Long-term efficacy of reverse pull headgear therapy. Angle Orthod 2006;76:915-22.

28. Celikoglu M, Yavuz I, Unal T, Oktay H, Erdem A. Comparison of the soft and hard tissue effects of two different protraction mechanisms in class III patients: a randomized clinical trial. Clin Oral Investig 2015;19:2115-22

29. Rongo R, D'Antò V, Bucci R, Polito I, Martina R, Michelotti A. Skeletal and dental effects of Class III orthopaedic treatment: a systematic review and meta-analysis. J Oral Rehabil 2017;44:545-62.

30. Cozza P, Baccetti T, Mucedero M, Pavoni C, Franchi L. Treatment and posttreatment effects of a facial mask combined with a bite-block appliance in Class III malocclusion. Am J Orthod Dentofacial Orthop 2010;138:300-10.

31. Üçüncü N, Tortop $T$, Yüksel S. A comparison of chincap and maxillary protraction appliances in the treatment of skeletal Class III malocclusions. Eur J Orthod 2000;22:43-51.

32. Baik HS, Jee SH, Lee KJ, Oh TK. Treatment effects of Fränkel functional regulator III in children with Class III malocclusions. Am J Orthod Dentofacial Orthop 2004;125:294-301.

33. Masucci C, Franchi L, Defraia E, Mucedero M, Cozza P, Baccetti T. Stability of rapid maxillary expansion and facemask therapy: a longterm controlled study. Am J Orthod Dentofacial Orthop 2011;140:493500 .

\section{Sınıf III maloklüzyonun tedavisinde ağız-içi çift plak ile yüz maskesi kombine uygulamasının uzun dönem sonuçları: sefalometrik analiz}

\section{ÖZET}

AmAÇ: Sınıf III maloklüzyonun tedavisinde kullanılan ağıziçi çift plak ile yüz maskesi (AÇP-YM) kombine tedavisinin uzun dönem sonuçlarının büyüme potansiyeli bitmiş ya da bitmekte olan hastalarda değerlendirilmesidir.

GEREÇ VE YönTEM: Çalışmanın materyali AÇP-YM kombine tedavisi uygulanmış olan iskeletsel ve dişsel Sınıf III maloklüzyona sahip 13 hastaya (5 kIz, 8 erkek; ortalama kronolojik yaş: $11.1 \pm 1.40$ yıl) ait tedavi öncesi (T1), son- 
rası (T2) ve uzun dönem takip (T3) lateral sefalometrik ve el bilek radyografilerinden oluşturuldu. Ortalama AÇP-YM tedavi süresi $10.8 \pm 1.88$ aydır. T3 döneminde, el bilek büyüme ve gelişim safhası, MP3u veya Ru dönemidir. Ortalama takip süresi $5.0 \pm 1.98$ yıldır. Tedavi (T2-T1), takip (T3-T2) ve toplam (T3-T1) değişiklikleri değerlendirmek için Friedman iki yönlü ANOVA ve Wilcoxon işaretli sıralar testleri kullanıldı.

BuLgULAR: AÇP-YM tedavisi ile SNA ve ANB açılarında artış bulundu ( $p<0.001)$. Ancak bu parametrelerde T3-T2 döneminde önemli düzeyde bir değişiklik meydana gelmedi $\left[\mathrm{p}=0.655\right.$ (SNA), $\mathrm{p}=0.805$ (ANB)]. $\mathrm{N} \perp_{\mathrm{FH}}$-A mesafesi tedavi $(p<0.01)$ ve takip $(p<0.05)$ dönemlerinde önemli düzeyde arttı. Molar ilişkide, hem AÇP-YM tedavisi sırasında hem de toplam sürede önemli düzeyde bir artış meydana gel- di $(p<0.001)$. Overjet ise, tedavi $(p<0.001)$, takip $(p<0.05)$ ve toplam sürede $(p<0.001)$ önemli düzeyde arttı. Tedavi, takip dönemlerinde ve toplam sürede, üst keserlerde (U1/ NA) önemli düzeyde protrüzyon gözlendi $(p<0.05)$. U6/PP ve L6/MP açıları AÇP-YM tedavisi ile değişmezken, takip periyodunda ve toplam sürede bu parametrelerde önemli düzeyde azalma meydana geldi $(p<0.05)$.

SoNUÇ: AÇP-YM kombine tedavisi, Sınıf III maloklüzyonun tedavisinde etkili bulundu. Bu ortopedik tedavi ile meydana gelen iskeletsel ve dişsel sagital değişikliklerin uzun dönem takip periyodunda korunduğu gözlendi.

Anahtar Kelimeler: Angle Sınıf 3; maloklüzyon; ortodontik cihazlar; ortodonti; takip çalışmaları 